\title{
Assessment of the Effectiveness of Patterned Breathing Technique in Reduction of Pain During First Stage of Labour Among Primigravida Mothers
}

\author{
Lalhriatpuii, Manjusha Mahakarkar and Vaishali Taksande \\ Department of OBGY Nursing, Smt. Radhikabai Meghe Memorial College of Nursing, Datta Meghe Institute \\ of Medical Sciences (Deemed to be University), Sawangi (Meghe) Wardha, Maharashtra, India. \\ Corresponding author email: lalhriatpuiichhangte5@gmail.com
}

\begin{abstract}
Labour is an emotional phenomenon that encompasses both psychological and physiological processes. The active method of delivering a foetus is labour, which is characterized by frequent, painful uterine contractions that increase in frequency and intensity. (Dutta, D.C., 2004). There are different types of options to relieve work-related pain and assisting relaxation. Comfort techniques that provide natural pain relief during labour and childbirth can be highly helpful. Quantitative Research Approach and Non-randomized control group design was used, 56 subjects (28 experimental \&t 28 control group) were allotted. The breathing technique was given to the experimental group during each and every contraction at a rate of 30 mins interval 3 times whereas the control group was given conventional care $\&$ the pain level was assessed by using Wong weber's facial pain scale. The result showed that the tabulated value for $n=28-1$ i.e. $27 \mathrm{df}$ was 2.05. The calculated 't' value i.e. 15 are higher than the tabulated value at 5\% level of significance for overall pain score of primigravida mothers which is statistically acceptable level of significance. As a result, statistically, the Patterned Breathing Technique was helpful during the initial stage of labour among primigravida mothers in the experimental group. Hence the breathing technique was effective according to the present study and it could be useful to reduce the labour pain and also the pain perception.
\end{abstract}

KEY WORDS: PRIMIGRAVIDA MOTHERS, LABOUR, BREATHING EXERCISE, EXPERIMENTAL GROUP, CONTROL GROUP

\section{INTRODUCTION}

Every birth comes from the pains of labour. The most difficult challenge is not to be pregnant with visions; it is to have an influence that encourages life. (Abd ELaziz et al., 2019). Pregnancy is a great and natural disease. Nine transformative months of suspense, preparing and peering at the amazing life unfolding. (Waghmare et al., 2018). Comfort in the sense of the pain of childbirth is a fascinating idea. The sense of comfort is an expression of having fulfilled present or imminent requirements or needs in three areas: body, mind and spirit. (Lowe 2002).

Biosc Biotech Res Comm P-ISSN: 0974-6455 E-ISSN: 2321-4007

\section{rossef}

Identifiers and Pagination

Year: 2021 Vol: 14 No (9) Special Issue

Pages: 262-267

This is an open access article under Creative

Commons License Attribn 4.0 Intl (CC-BY). DOI: $h t t p: / / d x$.doi.org/10.21786/bbrc/14.9.49
In order to improve their satisfaction with the delivery, it is important to inform future mothers about the process of natural delivery and potential pain relief techniques. Most of the parturient hope to receive adequate pain relief during childbirth and the aim of obstetrics practice is to select a procedure that will reduce the pain to a degree in which the parturient can cope with it and at the same time allow the parturient the opportunity to engage in the experience of birth. (Konlan et al., 2021).

In our nervous system, pain is a warning that something might be wrong. It's an awkward sensation, like a pinch, tingle, pain, burn, or ache. Maybe the pain is acute or dull. It might come and go, or it might be persistent. (Grahek, 2011). The pain of labour is intense, but his memory decreases over time, despite this. Labour is an emotional phenomenon that encompasses both psychological and physiological processes. The active method of delivering a foetus is labour, which is characterized by frequent, painful uterine contractions that increase in frequency and intensity. (Labor et al., 2008).
Article Information

Received: $17^{\text {th }} \mathrm{Apr} 2021$

ccepted after revision: $20^{\text {th }}$ June 2021 
During labour, pain is caused by contractions of the uterine muscles and pressure on the cervix. This discomfort, as well as an achy feeling, can be felt as heavy cramping in the abdomen, groin, and back. Some women often suffer from pain in their sides or thighs. (Murphy \& 2018). There are many ways, both pharmacological and non-pharmacological, to relieve work pain and help to relax. During labour and childbirth, comfort measures that offer natural pain relief can be very effective. (Leeman et al., 2003). Patterned techniques of breathing offer relaxation and concentration while improving the progress of labour. This increases the supply of oxygen to your baby and is also essential for the contracted uterus. (Waghmare et al., 2018).

The aim of the study is to assess the effectiveness of patterned breathing technique in reduction of pain during first stage of labour among primigravida mothers. The objectives of the study were to assess the pain during first stage of labour among primigravida mothers in control group, to assess the effectiveness of patterned breathing technique during first stage of labour among primigravida mothers in experimental group after intervention, to compare the pain level among primigravida mothers in experimental \&t control group, to find out the association between patterned breathing technique in reduction of pain during first stage of labour among primigravida mothers with selected demographic variables in control ct experimental group.

\section{METHODS}

In this study, the Quantitative Research approach and non- randomized control group design was used. The population was primigravida mothers during the first stage of labour; the samples consisted of 56(28 control Et 28 experimental group) of selected hospital of Wardha who have fulfilled the sample selection criteria according to the Non-Probability Convenient Sampling technique. The tool used in this study was Numeric Pain Intensity Scale specifically Wong Baker's Faces Pain Rating Scale. The validity of the tool was done by 10 experts. To achieve the study's goal, the investigator approached primigravida mothers in a designated location during the initial stage of labour and described the study's purpose as well as how it would benefit them. Her questioned about their desire to take part in the study and gained their agreement. During the initial stage of labour, the individuals were divided into two groups: experimental and control, soon when the cervical dilation was at $4 \mathrm{~cm}$, the pain was assessed in both group and the patterned breathing technique was given among experimental group, three times, 30 mins interval and the pain was assessed again after the intervention and without intervention in both group.

Table 1. Section A:Distribution of primigravida mothers according to their demographic characteristics. $n=56(28+28)$

\begin{tabular}{|c|c|c|c|c|}
\hline \multirow{2}{*}{$\begin{array}{c}\text { Demographic } \\
\text { Variables }\end{array}$} & \multicolumn{2}{|c|}{ Control Group } & \multicolumn{2}{|c|}{ Experimental Group } \\
\hline & Frequency(f) & Percentage $(\%)$ & Frequency(f) & Percentage $(\%)$ \\
\hline \multicolumn{5}{|c|}{ Age in year } \\
\hline $18-22$ yrs & 14 & $50 \%$ & 8 & $28.6 \%$ \\
\hline $23-27$ yrs & 10 & $35.7 \%$ & 15 & $53.6 \%$ \\
\hline $28-32$ yrs & 3 & $10.7 \%$ & 5 & $17.9 \%$ \\
\hline $33-37$ yrs & 1 & $3.6 \%$ & 0 & $0 \%$ \\
\hline \multicolumn{5}{|c|}{ Residence } \\
\hline Rural & 15 & $53.6 \%$ & 15 & $53.6 \%$ \\
\hline Urban & 13 & $46.4 \%$ & 13 & $46.4 \%$ \\
\hline \multicolumn{5}{|c|}{ Type of family } \\
\hline Joint & 20 & $71.4 \%$ & 20 & $71.4 \%$ \\
\hline Nuclear & 8 & $28.6 \%$ & 8 & $28.6 \%$ \\
\hline \multicolumn{5}{|c|}{ Education } \\
\hline Primary & 5 & $17.9 \%$ & 3 & $10.7 \%$ \\
\hline Middle School & 8 & $28.6 \%$ & 2 & $7.1 \%$ \\
\hline High School & 7 & $25 \%$ & 8 & $28.6 \%$ \\
\hline Higher Secondary & 6 & $21.4 \%$ & 9 & $32.1 \%$ \\
\hline Graduate & 2 & $7.1 \%$ & 6 & $21.4 \%$ \\
\hline \multicolumn{5}{|c|}{ Occupation } \\
\hline Homemaker & 18 & $64.3 \%$ & 15 & $53.6 \%$ \\
\hline Govt Servant & 2 & $7.1 \%$ & 3 & $10.7 \%$ \\
\hline Private Employee & 5 & $17.9 \%$ & 6 & $21.4 \%$ \\
\hline Others & 3 & $10.7 \%$ & 4 & $14.3 \%$ \\
\hline
\end{tabular}

\section{RESULTS}

The above table shows that $3(10.7 \%)$ of primigravida women in pre-test had hurts a little bit more i.e., face - 4, $16(57.1 \%)$ at pre-test and $3(10.7 \%)$ at post-test had hurts even more(face-6), 8(28.6\%) at pre-test and16(57.1\%) at post-test had hurts a whole lot (face -8 ) and $1(3.6 \%)$ of primigravida mothers in pre-test and $9(32.1 \%)$ in posttest had hurts worst(face-10) level of pain score. Range 
of pain score in pre and post were 4-10 \& 6-10. Mean score in pre and post were $6.50 \pm 1.40$ \&t $8.42 \pm 1.25$

The above table shows that $4(14.3 \%)$ of primigravida women in post-test had hurts a little bit i.e., face - 2, $12(42.9 \%)$ of primigravida mothers in post-test had hurts a little bit more (face - 4). 4(14.3\%) at pre-test and $9(32.1 \%)$ at post-test had hurts even more (face 6), $15(53.6 \%)$ at pre-test and $3(10.7 \%)$ at post-test had hurts a whole lot(face-8) and $9(32.1 \%)$ of primigravida mothers in pre-test had hurts worst(face-10) level of pain score. Range of pain score in pre \& post were 6-10 \&t 2 -8. Mean pain score in pre $\&$ post were $5.35 \pm 1.33$ \&t $4.78 \pm 1.55$.

\begin{tabular}{|c|c|c|c|c|c|}
\hline \multirow[t]{2}{*}{ SR. NO } & \multirow[t]{2}{*}{ Level of pain } & \multicolumn{2}{|c|}{ Pre-test } & \multicolumn{2}{|c|}{ Post-test } \\
\hline & & Frequency & Percentage & Frequency & Percentage \\
\hline 1 & Doesn’t hurt at all (Face - 0) & 0 & $0 \%$ & 0 & $0 \%$ \\
\hline 2 & Hurts just a little bit (Face-2) & 0 & $0 \%$ & 0 & $0 \%$ \\
\hline 3 & Hurts a little bit more (face-4) & 3 & $10.7 \%$ & 0 & $0 \%$ \\
\hline 4 & Hurts even more (Face - 6) & 16 & $57.1 \%$ & 3 & $10.7 \%$ \\
\hline 5 & Hurts a whole lot (Face - 8) & 8 & $28.6 \%$ & 16 & $57.1 \%$ \\
\hline 6 & Hurts worst (Face - 10) & 1 & $3.6 \%$ & 9 & $32.1 \%$ \\
\hline Range & $4-10$ & & $6-10$ & & \\
\hline $\mathrm{Mean}_{ \pm} \mathrm{SD}$ & $6.50 \pm 1.40$ & & $8.42 \pm 1.25$ & & \\
\hline
\end{tabular}

Figure1: Assessment with level of pain score in control group

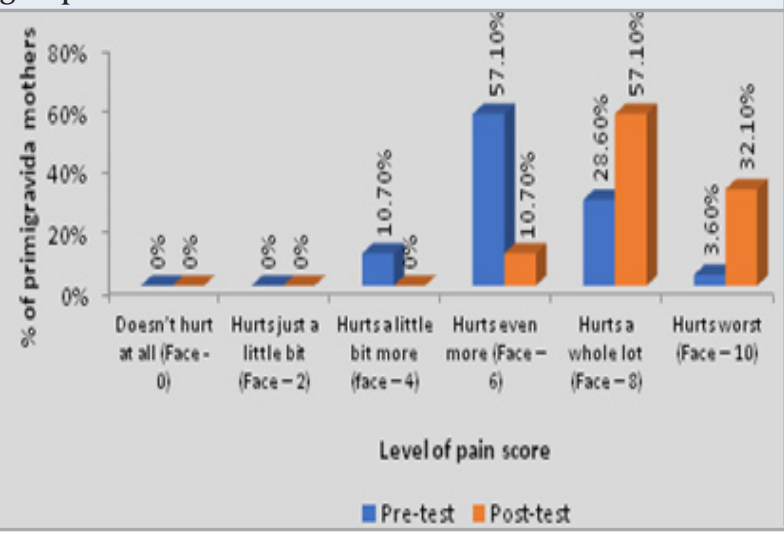

SECTION B.2: Assessment with level of pain score in experimental group $n=28$

\begin{tabular}{|l|c|c|c|}
\hline SR.NO & Level of pain & Pre-test & Post-test \\
\hline 1 & Doesn't hurt at all (Face - 0) & $0(0 \%)$ & $0(0 \%)$ \\
\hline 2 & Hurts just a little bit (Face - 2) & $0(0 \%)$ & $4(14.3 \%)$ \\
\hline 3 & Hurts a little bit more (face - 4) & $0(0 \%)$ & $12(42.9 \%)$ \\
\hline 4 & Hurts even more (Face - 6) & $4(14.3 \%)$ & $9(32.1 \%)$ \\
\hline 5 & Hurts a whole lot (Face - 8) & $15(53.6 \%)$ & $3(10.7 \%)$ \\
\hline 6 & Hurts worst (Face - 10) & $9(32.1 \%$ & $0(0 \%)$ \\
\hline Range & $6-10$ & $2-8$ & \\
\hline Mean \pm SD & $5.35 \pm 1.33$ & $4.78 \pm 1.55$ & \\
\hline
\end{tabular}

This table shows that the mean, standard deviation $\mathcal{E}$ mean difference values are compared \&t student's paired ' $t$ ' test is applied at 5\% level of significance. The tabulated value for $n=28-1$ i.e. 27 degrees of freedom was 2.05. The calculated ' $t$ ' value i.e. 15 are much higher than the tabulated value at 5\% level of significance for overall pain score of primigravida mothers which is statistically acceptable level of significance. Hence it is statistically interpreted that the Patterned Breathing Technique during first stage of labour among primigravida mothers in experimental group was effective. Thus, the $\mathrm{H} 1$ is accepted.

Figure 2: Assessment with level of pain score in experimental group

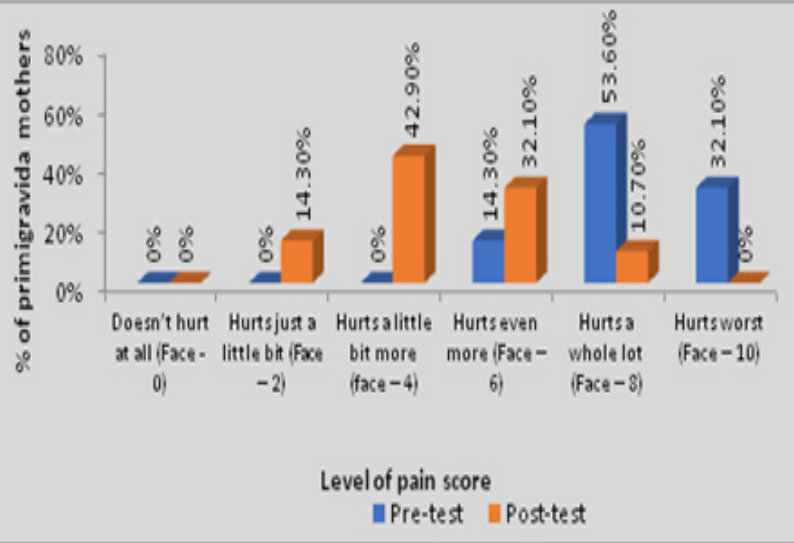

SECTION C: Significance of difference between pain score in pre and post test of primigravida mothers in experimental group

\begin{tabular}{|l|c|l|c|c|c|}
$\begin{array}{l}\text { Pain } \\
\text { Score }\end{array}$ & Mean & SD & $\begin{array}{c}\text { Mean } \\
\text { Difference }\end{array}$ & $\begin{array}{c}\mathrm{t}- \\
\text { value }\end{array}$ & $\begin{array}{c}\mathrm{p}- \\
\text { value }\end{array}$ \\
\hline Pre Test & 8.35 & 1.33 & $3.57 \pm 1.25$ & 15 & $\begin{array}{c}0.0001 \\
\mathrm{~S}, \mathrm{p}<0.05\end{array}$ \\
\hline Post Test & 4.78 & 1.75 & & & \\
\hline
\end{tabular}


Figure 4: Comparison of post test pain score among primigravida mothers in control and experimental group

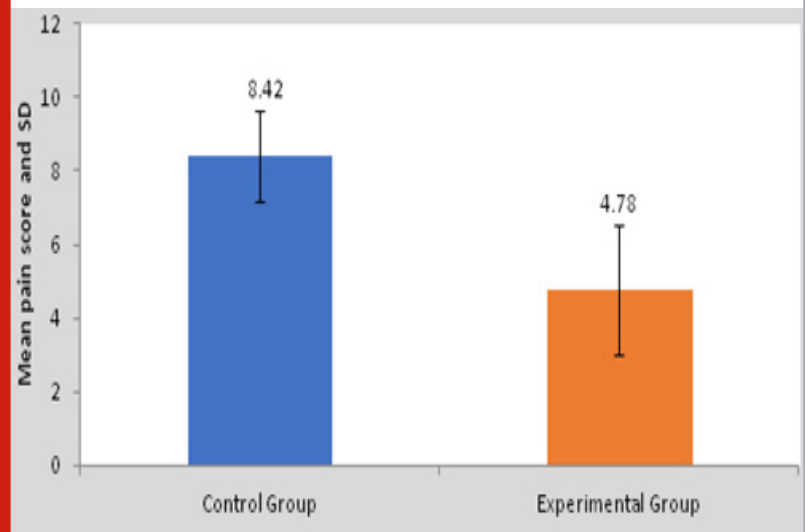

The mean, standard deviation, and mean difference values are compared in this table, and the student's unpaired t test is used at a significance level of $5 \%$. The tabulated value for $n=28+28-2$ i.e. 54 degrees of
SECTION D: Comparison of post test pain score among primigravida mothers in control and experimental group

\begin{tabular}{|l|l|l|l|l|l|}
\hline Group & Mean & SD & $\begin{array}{c}\text { Mean } \\
\text { Difference }\end{array}$ & $\begin{array}{c}\mathrm{t}- \\
\text { value }\end{array}$ & $\begin{array}{c}\mathrm{p}- \\
\text { value }\end{array}$ \\
\hline $\begin{array}{l}\text { Control } \\
\text { Group }\end{array}$ & 8.42 & 1.25 & $3.64 \pm 0.40$ & 8.93 & $\begin{array}{c}0.0001 \\
\mathrm{~S}, \mathrm{p}<0.05\end{array}$ \\
\hline $\begin{array}{c}\text { Experimental } \\
\text { Group }\end{array}$ & 4.78 & 1.75 & & & \\
\hline
\end{tabular}

freedom was 2.00. The calculated ' $t$ ' value i.e. 8.93 are much higher than the tabulated value at 5\% level of significance for overall pain score of primigravida mothers which is statistically acceptable level of significance. Hence it is statistically interpreted that the Patterned Breathing Technique during first stage of labour among primigravida mothers in control group was effective. Thus, the H1 is accepted.

There is no significant association between age, family, or occupation but there is a significant association with residence in the experimental group.

Section E.1: Association of post test pain score among primigravida mothers with their demographic variable in control group. $\mathrm{n}=28$

\begin{tabular}{|c|c|c|c|c|c|}
\hline & \multicolumn{2}{|c|}{ No. of primigravida mothers } & \multirow{2}{*}{$\begin{array}{l}\text { Mean post-test } \\
\text { pain score }\end{array}$} & \multirow{2}{*}{ F-value } & \multirow{2}{*}{ p-value } \\
\hline & Frequency(f) & Percentage $(\%)$ & & & \\
\hline \multicolumn{6}{|c|}{ Age in year } \\
\hline $18-22$ yrs & 14 & $50 \%$ & $8.42 \pm 1.15$ & \multirow{4}{*}{0.63} & \multirow{4}{*}{$\begin{aligned} & 0.59 \\
& \mathrm{NS}, \mathrm{p}>0.05\end{aligned}$} \\
\hline $23-27$ yrs & 10 & $35.7 \%$ & $8.20 \pm 1.47$ & & \\
\hline $28-32$ yrs & 3 & $10.7 \%$ & $8.66 \pm 1.15$ & & \\
\hline $33-37$ yrs & 1 & $3.6 \%$ & $10 \pm 0$ & & \\
\hline \multicolumn{6}{|c|}{ Residence } \\
\hline Rural & 15 & $53.6 \%$ & $8.26 \pm 1.03$ & \multirow{2}{*}{0.72} & \multirow{2}{*}{$\begin{array}{c}0.47 \\
\mathrm{NS}, \mathrm{p}>0.05\end{array}$} \\
\hline Urban & 13 & $46.4 \%$ & $8.61 \pm 1.50$ & & \\
\hline \multicolumn{6}{|c|}{ Type of family } \\
\hline Joint & 20 & $71.4 \%$ & $8.20 \pm 1.10$ & \multirow{2}{*}{1.55} & \multirow{2}{*}{$\begin{array}{c}0.13 \\
\mathrm{NS}, \mathrm{p}>0.05\end{array}$} \\
\hline Nuclear & 8 & $28.6 \%$ & $9 \pm 1.51$ & & \\
\hline \multicolumn{6}{|c|}{ Educational level } \\
\hline Primary & 5 & $17.9 \%$ & $8.40 \pm 0.89$ & \multirow{5}{*}{1.35} & \multirow{5}{*}{$\begin{aligned} 0.28 \\
\text { NS, } p>0.05\end{aligned}$} \\
\hline Middle School & 8 & $28.6 \%$ & $8.75 \pm 1.03$ & & \\
\hline High School & 7 & $25 \%$ & $8 \pm 1.63$ & & \\
\hline Higher Secondary & 6 & $21.4 \%$ & $8 \pm 1.26$ & & \\
\hline Graduate & 2 & $7.1 \%$ & $10 \pm 0$ & & \\
\hline \multicolumn{6}{|c|}{ Occupation } \\
\hline Homemaker & 18 & $64.3 \%$ & $8.44 \pm 1.29$ & \multirow{4}{*}{1.40} & \multirow{4}{*}{$\begin{array}{c}0.26 \\
\text { NS, } p>0.05\end{array}$} \\
\hline Govt Servant & 2 & $7.1 \%$ & $10 \pm 0$ & & \\
\hline Private Employee & 5 & $17.9 \%$ & $8 \pm 1.41$ & & \\
\hline Others & 3 & $10.7 \%$ & $8 \pm 0$ & & \\
\hline
\end{tabular}


SECTION E.2: Association of post test pain score among primigravida mothers with their demographic variable in experimental group. $n=28$

\begin{tabular}{|c|c|c|c|c|c|}
\hline & \multicolumn{2}{|c|}{ No. of primigravida mothers } & \multirow{2}{*}{$\begin{array}{c}\text { Mean post-test } \\
\text { pain score }\end{array}$} & \multirow{2}{*}{ F-value } & \multirow{2}{*}{ p-value } \\
\hline & Frequency(f) & Percentage $(\%)$ & & & \\
\hline \multicolumn{6}{|c|}{ Age in year } \\
\hline $18-22$ yrs & 8 & $28.6 \%$ & $5.75 \pm 2.25$ & \multirow{4}{*}{1.80} & \multirow{4}{*}{$\begin{array}{c}0.18 \\
\mathrm{NS}, \mathrm{p}>0.05\end{array}$} \\
\hline $23-27$ yrs & 15 & $53.6 \%$ & $4.40 \pm 1.35$ & & \\
\hline $28-32$ yrs & 5 & $17.9 \%$ & $4.40 \pm 1.67$ & & \\
\hline $33-37$ yrs & 0 & $0 \%$ & $10 \pm 0$ & & \\
\hline \multicolumn{6}{|c|}{ Residence } \\
\hline Rural & 15 & $53.6 \%$ & $5.46 \pm 1.59$ & \multirow{2}{*}{2.39} & \multirow{2}{*}{$\begin{array}{c}0.024 \\
\mathrm{~s}, \mathrm{P}<0.05\end{array}$} \\
\hline Urban & 13 & $46.4 \%$ & $4 \pm 1.63$ & & \\
\hline \multicolumn{6}{|c|}{ Type of family } \\
\hline Joint & 20 & $71.4 \%$ & $4.90 \pm 1.77$ & \multirow{2}{*}{0.53} & \multirow{2}{*}{$\begin{array}{c}0.59 \\
\mathrm{NS}, \mathrm{p}>0.05\end{array}$} \\
\hline Nuclear & 8 & $28.6 \%$ & $4.50 \pm 1.77$ & & \\
\hline \multicolumn{6}{|c|}{ Educational level } \\
\hline Primary & 3 & $10.7 \%$ & $5.33 \pm 2.30$ & \multirow{5}{*}{0.72} & \multirow{5}{*}{$\begin{array}{c}0.58 \\
\mathrm{NS}, \mathrm{p}>0.05\end{array}$} \\
\hline Middle School & 2 & $7.1 \%$ & $3 \pm 1.41$ & & \\
\hline High School & 8 & $28.6 \%$ & $5.25 \pm 1.48$ & & \\
\hline Higher Secondary & 9 & $32.1 \%$ & $4.66 \pm 2$ & & \\
\hline Graduate & 6 & $21.4 \%$ & $4.66 \pm 1.63$ & & \\
\hline \multicolumn{6}{|c|}{ Occupation } \\
\hline Homemaker & 15 & $53.6 \%$ & $5.33 \pm 1.79$ & \multirow{4}{*}{1.19} & \multirow{4}{*}{$\begin{array}{c}0.33 \\
\mathrm{NS}, \mathrm{p}>0.05\end{array}$} \\
\hline Govt Servant & 3 & $10.7 \%$ & $4.66 \pm 1.15$ & & \\
\hline Private Employee & 6 & $21.4 \%$ & $4 \pm 2.19$ & & \\
\hline Others & 4 & $14.3 \%$ & $4 \pm 0$ & & \\
\hline
\end{tabular}

\section{DISCUSSION}

In this study, the distribution of primigravida mothers after post test shows that 3(10.7\%) had hurts even more(face-6), 16(57.1\%) had hurts a whole lot (face - 8), $9(32.1 \%)$ had hurts worst(face-10) level of pain score. While in experimental group 4(14.3\%) had hurts a little bit i.e., face - 2, 12(42.9\%) of primigravida mothers had hurts a little bit more (face - 4). 9(32.1\%) had hurts even more (face -6$), 3(10.7 \%)$ had hurts a whole lot(face-8) level of pain score. In assessment of effectiveness of patterned breathing technique. The tabulated value for $n=28-1$ i.e. 27 degrees of freedom was 2.05. The calculated ' $t$ ' value i.e. 15 are much higher than the tabulated value at 5\% level of significance for overall pain score of primigravida mothers which is statistically acceptable level of significance.

The similar study conducted Jose KE states that the mean value of pre and post intervention score were 14.09, 8.03 respectively and the mean difference was $6.057 \mathrm{Ct}$ $t$ value of 35.8 and was found to be significant at 0.001 level among interventional group. The mean value post intervention score was 8.03 with SD of 1.014 among interventional group and the mean post intervention score was 12.34 with standard deviation of 1.679 among control group. The mean difference was 4.314. The t-value 13.010 was found to be significant at 0.001 level between interventional and control group. (JOSE, K.E., 2012) In the this study, there is no significant association in control group. While in experimental group, the significant association was found with residence.

The findings was supported by the study conducted by Shruti. L at a selected hospital in Mangalore. The experimental and control group post-assessment levels of labour pain perception showed no statistically significant association with chosen demographic characteristics such as age, religion, family type, education, and residential location, as well as employment pattern. (Sruthi, L., 2013)

\section{CONCLUSION}

The breathing technique was effective according to the present study and it could be useful to reduce the labour pain and also the pain perception.

\section{REFERENCES}

Abd ELaziz, H.M., Elsayed, L.A. and Ramaya, P., (2019). Effect of Acupressure on Duration of Labor and Intensity of Labor Pain.

Dutta, D.C., (2004). Text book of obstetrics: including perinatology and contraception. New central book agency.

Grahek, N., (2011). Feeling pain and being in pain. mit Press.

JOSE, K.E., (2012). A quasi experimental study to assess the effectiveness of modified lamaze method on labour 
pain among parturient mothers admitted in selected hospital at bangalore (Doctoral dissertation).

Konlan, K.D., Afaya, A., Mensah, E., Suuk, A.N. and Kombat, D.I., (2021). Non-pharmacological interventions of pain management used during labour; an exploratory descriptive qualitative study of puerperal women in Adidome Government Hospital of the Volta Region, Ghana. Reproductive Health, 18(1), pp.1-11.

Labor, S. and Maguire, S., (2008). The pain of labour. Reviews in pain, 2(2), pp.15-19.

Leeman, L., Fontaine, P., King, V., Klein, M.C. and Ratcliffe, S., (2003). The nature and management of labor pain: part I. Nonpharmacologic pain relief. American Family Physician, 68(6), pp.1109-1112.
Lowe, N.K.,( 2002). The nature of labor pain. American journal of obstetrics and gynecology, 186(5), pp.S16S24.

Murphy, J., (2018). KidsHealth< www. kidshealth. org $>$. Journal of Consumer Health on the Internet, 22(4), pp.362-370.

Ordaz, 0. and Hober, C., (2020). Effects of Waterbirth on Laboring Women.

Sruthi, L., (2013). Effectiveness of breathing exercises on Labour pain among primi mothers At selected hospital In mangalore (Doctoral dissertation).

Waghmare, J. and Bhore, N.R., (2018). Effectiveness of calendula Oil Application on LsCs Wound Healing among Mothers Who has Undergone Lscs. Amarjeet Kaur Sandhu, 10(4), p.64. 